\title{
COMPARANDO OS ESCRITOS DO NEOATEÍSMO (NAT): EM BUSCA DE UMA DEFINIÇÃO
}

COMPARING THE WRITING OF NEW ATHEISM (NAT): IN SEARCH OF A DEFINITION

Adilson Koslowski*

Valmor Santos**

\section{RESUMO}

O objetivo do texto é buscar uma definição de neoateísmo (NAT). Para isso, sintetizamos as ideias fundamentais do movimento a partir de seus autores e de suas obras fundamentais. Os intelectuais do movimento são muitos, porém os principais e mais famosos são quatro, a saber, Richard Dawkins, Sam Harris, Daniel Dennett e Christopher Hitchens. As obras que consideramos serem os manifestos do NAT são: O fim da fé e Carta à nação, de Harris; Deus, um delírio, de Dawkins; Quebrando o encanto, de Dennett; e Deus não é grande, de Hitchens. Optamos por um modo de definir conforme a técnica wittgensteiniana de semelhança de família. Significa que não oferecemos uma definição em termos de condições necessárias e suficientes. Nossa opção se deve ao fato de que o NAT é formado por vários intelectuais que compartilham certas ideias, mas não são concordes em todos os aspectos. Além disso, é um movimento em atividade e suas posições podem se modificar; um movimento aberto que recebe outras pessoas comprometidas com ideias semelhantes.

PALAVRAS-CHAVE: Definição. Dawkins. Harris. Dennett. Hitchens.

\section{ABSTRACT}

The objective this paper is to seek a definition of New Atheism (NAT). For this, we synthesized the fundamental ideas of the movement from its authors and their fundamental works. Movement of intellectuals are many, but the main and most famous are four, namely, Richard Dawkins, Sam Harris, Daniel Dennett and Christopher Hitchens. Works we consider to be the NAT manifests are: The End of Faith (2004) and Letter to the nation, Harris; God Delusion, Dawkins; Breaking the Spell, Dennett; and God is not great, Hitchens. We restricted to four. We do not offer a definition in terms of necessary and suficiente conditions, but we opted for a way to define as Wittgenstein's technique family resemblance. Our choice

\footnotetext{
* Doutor em Filosofia. Professor de Filosofia do Departamento da UFS/DFL. E-mail: kadilson@ibest.com.br.

** Mestre em Ciências da Religião - UFS. valmor4@ hotmail.com.
} 
is due to the fact that NAT is formed of intelectual various sharing certain ideas, but are not concordant in all aspects. Furthermore, its is a movement in activity and their postions can be changed, and is open other people involved with similar ideas.

KEYWORDS: Defintion. Dawkins. Harris. Dennett. Hitchens.

\section{INTRODUÇÃO}

O neoateísmo (NAT) supostamente é um movimento que tem entre seus mentores quatro pais fundadores. São os conhecidos e midiáticos Sam Harris, Richard Dawkins, Daniel Dennett e Christopher Hitchens. Alguns dos seus livros são considerados "manifestos" do movimento. Os cinco livros que se destacam são A morte da fé (2004), Carta a uma nação cristã (2006), Deus, um delírio (2006), Quebrando o encanto: a religião como fenômeno natural (2006) e Deus não é grande: como a religião envenena tudo (2007).

O presente artigo tem o objetivo de fazer comparações entre esses escritos, estabelecendo posições comuns ou divergências quanto a essa alegada posição comum ateísta. Com tal finalidade, elegemos alguns tópicos para orientar nossa comparação. Escolhemos nove pontos de comparação: Deus ou deuses, religião, moralidade, sociedade, política, educação, ciência, Estado e gênero/sexualidade. A escolha por esses tópicos foi determinada pela importância que eles têm em uma concepção ateísta que é compreendida como estando em movimento. Ela abrange tópicos teológicos, morais, políticos, sociais, entre outros. São tópicos que a nosso ver cobrem de modo satisfatório uma comparação entre os escritos desses autores.

Essa comparação possibilitará ver a proximidade de concepções entre os neoateístas, bem como as possíveis diferenças, auxiliando-nos no próximo capítulo, em que faremos uma caracterização do movimento e uma análise crítica de várias suposições que assumimos até o presente momento a respeito do NAT.

$\mathrm{O}$ artigo se divide em quatro partes. Na primeira parte, faremos uma apresentação biográfica curta de cada um dos quatro ateístas; na segunda parte, sintetizaremos as posições dos autores em relação aos nove tópicos estabelecidos. Na terceira parte, compararemos as semelhanças e diferenças entre as ideias que sustentam a respeito dos tópicos. Por fim, apresentaremos uma definição de neoateísmo. A primeira e a segunda parte serão apresentadas de forma intercalada. 


\section{SAM HARRIS: A MORTE DA FÉ}

Iniciaremos nossa exposição com o filósofo e neurocientista Sam Harris, pois ele é o autor do primeiro escrito do movimento - A morte da fé: religião, terror e o futuro da razão (2004) - e de Carta a uma nação cristã (2006).

Jenin Younes, em seu artigo Sam Harris, publicado em Icons of unbelief: atehists, agnostics, and Secularists (2008), faz uma síntese dos principais dados biográfico de Harris. O episódio que marcou a obra de Harris foi o 11 de setembro de 2001, quando mulçumanos tomaram quatro aviões e lançaram dois deles contra o World Trade Center, nos Estados Unidos. Houve várias intepretações sobre o ocorrido, porém a intepretação de que se tratava de uma motivação eminentemente religiosa foi a defendida por Harris (YOUNES, 2009, p. 141).

Harris nasceu em Los Angeles, em 1967. Seu pai era um quaker, sua mãe uma judia, mas sua educação não foi religiosa. Ele desistiu aos 19 anos da Universidade de Stanford, após suas experiências com drogas que alteram os estados da consciência; fez viagens ao redor do mundo, e estudou as religiões, o budismo em particular. Zenk (2013, p. 247) afirma que Harris é budista praticante, não obstante sem dogmas (YOUNES, 2009, p. 146). Em 1997, retornou a Stanford e completou a graduação em filosofia. Também completou um doutorado em neurociências, com um estudo sobre as diferenciações cerebrais nos estados de crença, não crença e incerteza (YOUNES, 2009, p. 141-42).

O 11 de setembro foi para Harris o momento que fez o crítico do fundamentalismo vir à tona. Seu livro A morte da fé viria a lume três anos depois, em 2004, tornando-se um bestseller durante semanas nos Estados Unidos. Em 2006, escreveu Uma carta a uma nação cristã, em resposta às críticas que seu livro havia recebido. A tese mais contestada no livro foi a alegação de Harris de que os religiosos moderados são responsáveis pelo fundamentalismo, pois aceitam crenças não racionalmente fundamentadas e pedem respeito por elas; assim, a porta está aberta para os fundamentalismos. Uma análise das crenças religiosas baseadas na fé não seria justificada, segundo Harris (YOUNES, 2009, p. 142), o qual sustenta que as alegações da fé teriam que ser tomadas como outras proposições empíricas que fazemos e, portanto, deveriam ser submetidas a teste empírico (YOUNES, 2009, p. 142).

Sam Harris é cofundador do Project Reason, uma fundação sem fins lucrativos com a finalidade de promover a pesquisa, as artes, a educação, a publicação de livros, entre outras atividades, para o pensamento crítico não dogmático ou supersticioso.

O livro de Sam Harris A morte da fé: religião, terror e o futuro da razão (2004; 2009) é a obra ateísta principal de Harris e a primeira associada ao NAT. Reforçando, o contexto da 
obra é uma reação aos acontecimentos do ataque ao World Trade Center em 2001. O livro consta de sete capítulos. Os dois primeiros estão centrados na questão da crença e de sua natureza, e são os capítulos mais importantes; todos os demais estão principalmente focados em elucidar e explicar a ideia central de que a fé religiosa é um mal que deve ser extirpado, pois "é a fé que mantém em pé todo esse terrível edifício da certeza religiosa que tão perigosamente ameaça o nosso mundo" (YOUNES, 2009, p. 270). No terceiro, quarto e quinto capítulos, Harris mostra as nefastas consequências da fé religiosa, a saber: a inquisição e o holocausto frutos da fé cristã; o fundamentalismo islâmico e a influência negativa na vida pública americana do protestantismo fundamentalista. O sexto capítulo tem como tema a ética, sua racionalidade e os problemas do relativismo. No último capítulo, o autor desenvolve a necessidade da espiritualidade e do misticismo sem laços com a dogmática religiosa, bem como sua importância para a felicidade e para a ética. Há ainda um posfácio, bastante breve, para responder a algumas objeções que Harris recebeu de leitores quanto à primeira edição.

Para Harris (2009, p. 12-13), o problema fundamental não é a religião em si mesma, mas o fato de ela pedir aos seus membros que acreditem em certas proposições sem ter evidências suficientes que justifiquem admitir para si o conteúdo dessas crenças; isto é, a fé, “consiste em crer em afirmações históricas e metafísicas sem provas suficientes" (HARRIS, 2009, p. 269). Uma crença só deve ser admitida quando temos evidências (razões) suficientemente fortes para isso, e nunca devemos crer em uma proposição que não forneça tal conteúdo.

Segundo Harris (2009, p. 14-15), na vida cotidiana, na ciência bem como em outros setores, exigimos sempre provas, evidências para as alegações e para as crenças, porém, no campo das crenças religiosas esse princípio não é aplicado. Aí não só é possível crer sem provas, mas é louvável. Para Harris, as proposições religiosas são semelhantes a outras proposições e não deve haver exceção. As proposições religiosas também devem ser admitidas somente quando há razões para serem legitimamente admitidas. As crenças religiosas não devem ser admitidas apenas por autoridade religiosa, sejam crenças contidas na Bíblia ou no Corão, por exemplo.

No segundo capítulo de seu livro A Morte da fé, Harris (2009, p. 57-58) compreende a crença como uma atitude a respeito de uma proposição. O conteúdo de uma crença é uma proposição. Uma proposição é o significado de uma sentença, que pode ser verdadeira ou falsa. Nós temos várias atitudes perante uma crença de raiva, de alegria etc., podendo acreditar que o conteúdo que ela representa é verdadeiro ou falso. Os religiosos tomam 
algumas de suas crenças como verdadeiras, porém não têm como justificá-las. São crenças infundadas. As crenças são princípios de ação, isto é, elas orientam nosso comportamento.

As religiões têm, ao longo da história, exigido de seus adeptos que sustentem crenças irracionais ou sem evidências. A crença em si não é perigosa, mas o problema, para Harris (2009, p. 20), é que as crenças informam nossas ações. Agimos geralmente do modo que pensamos a respeito de nós mesmo, dos outros e do mundo. E é nesse ponto que os problemas com as crenças tornam-se relevantes. Um dos exemplos favoritos de Harris é o caso do fiel mulçumano que morre como mártir em um ataque suicida para alcançar o paraíso e é um orgulho para a família (HARRIS, 2009, p. 9-10), mas ele oferece vários exemplos, ao longo do livro, de como algumas crenças religiosas expressam a violência, como o ódio ao não crente (HARRIS, 2009, p. 34).

As crenças, conforme Harris (2009, p. 60 e 65), devem ter certas características para poderem ser aceitas. Uma dessas propriedades é que as crenças têm de ser coerentes logicamente umas com as outras, devendo-se evitar a contradição em nosso sistema de crenças. Claro que essa regra é ideal, pois na realidade não temos um conjunto inteiramente coerente. Todavia, a coerência lógica não é suficiente: as crenças devem representar o mundo. Se as crenças representam o mundo, são verdadeiras; do contrário, são falsas.

Harris (2009, p. 13ss) critica não apenas as religiões fundamentalistas, isto é, que acreditam na literalidade absoluta de seu credo e de seus livros sagrados como revelação sem erro de Deus, mas os religiosos moderados, pois eles, em nome do direito à liberdade religiosa, tornam possível o fundamentalismo religioso. Não se podem criticar duramente as supostas "verdades da religião", pois moderados tanto pós-modernos como pluralistas consideram isso politicamente incorreto (HARRIS, 2009, p. 51). Porém, a moderação na religião não é uma virtude intrínseca à própria religião; no Ocidente, ela se deu pelo embate entre a religião e o pensamento moderno. A ciência moderna contribuiu e contribui para abandonarmos crenças infundadas, questionarmos proposições sem evidência (HARRIS, 2009, p. 18 e 20).

No entanto, Harris (2009, p. 26) não vê a religião em si mesma como um mal, quando entendida enquanto um conjunto de práticas em que algumas podem ser salvas e justificadas racionalmente. Ela providenciou identidade e união de grupos, de comunidades. Porém, segundo o autor, esse aspecto positivo da religião não é mais necessário, pois estamos vinculados em nossos dias por necessidades econômicas, ambientais, políticas, epidemiológicas, entre outras. A religião já não tem um papel relevante do ponto de vista da 
união entre os seres humanos. Ainda assim, na questão do sentido e na abertura do ser humano aos outros e ao mundo, Harris sustenta que as religiões, com sua tradição espiritual e mística, apontam para algo real e que deve ser levado em conta, desde que purificadas das crendices. Evidentemente, essa espiritualidade ou mística da religião deve ser baseada aos poucos na neurociência, porém essa realidade ainda não tem uma explicação completa, apesar de revelar uma dimensão espiritual humana real. Essa mística ou espiritualidade (em falta de um termo melhor) nos permite romper com os limites do nosso estreito "eu" (HARRIS, 2009, p. 44ss.). Em suas palavras:

tudo que é bom nas religiões pode ser encontrado em outras partes - por exemplo, se a experiência ética e espiritual puder ser cultivada e comentada sem a pretensão de saber coisas que evidentemente não sabemos -, então todo o resto da nossa atividade religiosa representa, na melhor das hipóteses, um enorme desperdício de tempo e energia. (HARRIS, 2009, p. 171).

A racionalidade científica não é suficiente, segundo Harris, para uma vida boa. Em suas palavras:

\footnotetext{
Não podemos viver apenas pela razão. É por isso que a razão aplicada como antisséptico, mesmo em grandes quantidades, não pode competir com o bálsamo da fé, a partir do momento em que os terrores deste mundo começam a invadir nossas vidas. Seu filho morreu, sua esposa contraiu uma horrível doença que nenhum médico pode curar, ou seu próprio corpo subitamente começou a se encaminhar para o túmulo - e a razão, por mais abrangente que seja, com certeza vai começar a ter cheiro de formol. (HARRIS, 2009, p. 48).
}

Para Harris (2009, p. 42), reportando-se a Freud, a religião tem sua força potencializada no medo da morte e nas ilusões ofertadas para a solução absoluta do que acontecerá no pós-morte. O medo da morte é um motivo para a fé. Se não fôssemos mortais, a influência da religião seria irrisória.

De acordo com Harris (2009, p. 89-91), o mundo corre grande perigo, pois a fé, seja ela religiosa ou secular (como nos casos de Stalin, Mao Tsé-Tung, Hitler) leva à violência e ao conflito armado. Segundo Harris (2009, p. 51), "as informações e tecnologias necessárias [para fabricar armas de destruição em massa] hoje estão se infiltrando em cada canto do mundo". Entre os exemplos mais sombrios da história da fé, Harris escolhe a inquisição e o holocausto. Em sua opinião, ambos têm sua agência na religião. No caso do holocausto, segundo Harris, séculos de antijudaísmo que remontam a escritos do Novo Testamento e séculos dessa atitude entre os alemães tornaram o antissemitismo possível; além disso, a 
igreja alemã da época de Hitler teria reforçado o ser judeu como uma raça. Esses dois casos são analisados no terceiro capítulo de Morte da fé (HARRIS, 2009, p. 92-122).

No fim do capítulo 4, sobre o Islã, Harris (2009, p. 162-169) critica a esquerda americana representada por Noam Chomsky, o relativismo moral, o pacifismo, e propõe a necessidade de um governo global. O filósofo e militante esquerdista Noam Chomsky, um implacável crítico da política externa americana, sustenta que os Estados Unidos são uma nação terrorista. Têm causado em várias partes do mundo muitas mortes e problemas. Harris chama atenção de que Chomsky está correto em afirmar que o país tem cometido muitos erros e que é por isso responsável, porém o erro do linguista e filósofo é não distinguir as intenções morais dos agentes americanos de outras. Chomsky estaria confundindo tudo.

No que concerne ao relativismo ético, não podemos afirmar, segundo Harris (2009, p. 165-167), que todos somos iguais moralmente. Há melhores e há piores. Usa a seguinte analogia: como há sociedades mais ricas do que outras, há também sociedades que têm mais riqueza moral. Há sim uma hierarquia, e nem todas as sociedades são iguais. Ele estende essa não relatividade a outras áreas. Conforme suas próprias palavras:

É inevitável, portanto, que algumas abordagens da política, da economia, da ciência e até mesmo da espiritualidade e da ética sejam objetivamente melhores do que suas concorrentes (seja qual for o critério de "melhor" que quisermos adotar), e essas gradações se traduzirão em diferenças bem reais na felicidade humana. (HARRIS, 2009, p. 167).

Quanto ao pacifismo, Harris (2009, p. 164) chama de "dogma" e uma "posição profundamente imoral". Sustenta (ibidem, p. 175-176) que o Ocidente pode controlar os excessos do Islã e evitar uma guerra de civilizações por meio de pressão externa, seja econômica ou por outros meios. Porém, quando isso não funcionar, a intervenção pela força será inevitável, para proteger os interesses do Ocidente em muitos assuntos.

Por fim, Harris (2009, p. 174-175) propõe e apoia, na esteira do filósofo Jonathan Glover (em seu livro Humanity: a moral history of the twentieth century, de 1999), um governo mundial que possa intervir tanto jurídica quanto militarmente para manter a paz entre as nações. Isso é muito difícil de acontecer, dada a dificuldade de integração econômica, cultural e moral, e a religião é um fator de desunião nesse tipo de empreendimento.

No capítulo 5, A oeste do Éden, Harris (2009) lamenta a interferência da direita cristã na política e na ética do Estado. A religião no Ocidente causa muitos malefícios; o problema em nossos dias não é exclusivo do Islã. Por exemplo, Ronald Reagan interpretava os 
acontecimentos do Oriente Médio com ajuda de pastores escatologistas, como Jarrey Falwell e Hal Lindsey, e o apoio para o retorno dos judeus à Palestina é inspirado nas profecias bíblicas do fim do mundo (HARRIS, 2009, p. 177-78). Essa influência religiosa se estende aos tribunais e aos conteúdos do currículo escolar (ibidem, p. 178-183).

A religião torna a moral um lugar para projetar sua noção de pecado, e assuntos como drogas, prostituição, sodomia e pornografia são criminalizados e tratados de um modo não racional devido às influências de grupos cristãos que interferem na vida pública, por meio das bancadas cristãs da direita conservadora (HARRIS, 2009, p. 183-191). Cite-se, ademais, a influência da religião nos atrasos das pesquisas com células-tronco - os cristãos sustentam que mesmo um embrião com alguns dias e com menos de 150 células (blastócito) é um ser humano com todos os direitos, pois ele recebeu uma alma imortal no momento da fecundação (HARRIS, 2009, p. 191-194).

A concepção de Deus de Harris é de que o deus das religiões abraâmicas é "um sujeito ridículo - caprichoso, petulante e cruel -, e fazer um pacto com ele não garante a saúde nem a felicidade" (HARRIS, 2009, p. 201). Harris também sustenta já sabermos "o suficiente para dizer que o Deus de Abraão não apenas não merece a imensidade de toda a Criação; ele não merece sequer o homem" (ibidem, p. 263).

\section{RICHARD DAWKINS: DEUS, UM DELÍRIO}

Conforme relatado por Donald R. Burleson (2008, p. 27), em Icons of unbelief, Richard Dawkins nasceu em Nairóbi, Quênia, em 1941. Seus pais voltaram para a Inglaterra quando ele tinha oito anos. Obteve seu doutorado em Oxford em 1966. Ensinou biologia em várias universidades em Berkeley e Oxford. Em 1995, aceitou o cargo de Entendimento Público da Ciência, uma instituição pública.

O livro que nos interessa é Deus: um delírio (2006), no qual Dawkins, considerado o principal membro do NAT, expressa seu ateísmo. O livro é constituído de dez capítulos e um apêndice. Contudo, entendemos que se constitua de duas partes. Os cinco primeiros capítulos são dedicados à discussão dos problemas ontológicos e epistêmicos a respeito da existência Deus. Os outros capítulos focalizam aspectos práticos como a moral, a origem da religião, a maldade da religião e o consolo da religião.

Em relação a Deus, o foco é fundamentalmente o Deus das religiões abraâmicas. Mas o livro examina principalmente a compreensão cristã de Deus, pois, como afirma o próprio 
Dawkins, é a religião que ele mais conhece. O seu foco não é o Deus do panteísta, de um Espinosa ou de um Einstein, mas principalmente o Deus do Antigo Testamento, Javé (DAWKINS, 2007, p. 44-45), comum ao judaísmo, ao cristianismo e ao Islã. Contudo, para simplificar, Dawkins nega todos os deuses, sejam do monoteísmo ou do politeísmo, e usa para ambos os posicionamentos religiosos o nome Deus (DAWKINS, 2007, p. 61). A tese básica de seu livro é a negação de qualquer tipo de supernaturalismo (DAWKINS, p. 62): "Estou atacando Deus, todos os deuses, toda e qualquer coisa que seja sobrenatural, que já foi e que ainda será inventada".

Em dois lugares do texto de Dawkins, é feita uma caracterização mais longa do Deus a que ele está se referindo:

\footnotetext{
intervencionista, milagreiro, telepata, castigador de pecados, atendedor de preces da Bíblia, dos padres, mulás e rabinos, e do linguajar do dia-a-dia. (DAWKINS, 2007, p. 44).

O Deus do Antigo Testamento é talvez o personagem mais desagradável da ficção: ciumento, e com orgulho; controlador mesquinho, injusto e intransigente; genocida étnico e vingativo, sedento de sangue; perseguidor, misógino, homofóbico, racista, infanticida, filicida, pestilento, megalomaníaco, sadomasoquista, malévolo. (DAWKINS, 2007, p. 55).
}

Com essa viva caracterização, fica bastante claro como Dawkins compreende o significado da palavra "Deus" em seu livro. No capítulo terceiro, intitulado Argumentos para a existência de Deus, o zoólogo pretende desconstruir algumas das clássicas provas ou argumentos a favor da existência de Deus. Ele faz uma análise das provas de Tomás de Aquino, as famosas cinco vias; analisa o argumento ontológico do monge medieval Anselmo, bem como outros argumentos a priori; o argumento da beleza, o da experiência religiosa ou mística, o argumento das escrituras de que Jesus seria Deus, da aposta de Pascal, os argumentos bayesianos (um tipo de argumento probabilístico). Dawkins os analisa e faz objeções, com o propósito de demonstrar que são falazes.

É no capítulo quarto, intitulado Por que quase com certeza Deus não existe, que Dawkins torna-se filósofo e constrói um argumento contra a existência de Deus. $\mathrm{O}$ argumento é novo, e tem como objetivo ser um argumento positivo a favor do ateísmo. Ele o denomina "argumento do 747 definitivo" (DAWKINS, 2007, p. 204), fazendo referência ao avião Boeing 747. A ideia geral do argumento é anular os argumentos cosmológicos que se baseiam no design inteligente. Esses argumentos carecem todos de um problema básico comum. Para explicar algum aspecto intrincado e muito complexo da realidade, pressupõem que não pode 
ser fruto do acaso, logo tendo que haver uma inteligência que planejou aquele complexíssimo projeto.

Dawkins desfaz o erro de interpretar a teoria da evolução como uma teoria que se baseia no acaso; diferentemente, a teoria se basearia num processo determinístico não guiado, que é a seleção natural. Os teístas apresentam Deus como solução para o problema da complexidade, porém não se perguntam sobre quem projetou algo tão complexo como Deus.

Se algo complexo precisa de explicação, pois não há uma explicação redutível concebida dentro das ciências biológicas, o que dizer da complexidade ao infinito do projetista? Todavia, a teoria da evolução não tematiza esse problema, pois seu objetivo é mostrar como de coisas simples podem surgir coisas complexas. $\mathrm{O}$ acúmulo de pequenas mudanças gera grandes mudanças.

De modo mais esquemático, tomamos a reformulação do argumento de Dawkins feita pelo filósofo Gary Gutting (2015): 1) Existe a necessidade por uma explicação do aparente projeto (design) do universo. 2) O universo é altamente complexo. 3) Um projetista inteligente (designer) do universo seria ele mesmo muito mais complexo. 4) Um projetista complexo requereria ele mesmo uma explicação. 5) Portanto, um projetista inteligente não providenciaria uma explicação da complexidade do universo. 6) Por outro lado, simples processos (individualmente) da seleção natural explicariam o aparente projeto do universo. 7) Portanto, um inteligente projetista (Deus), quase certamente não existe.

Quanto à religião, a compreensão de Dawkins (2007) pode ser resumida em três aspectos. A religião incita a fé, que por sua natureza é irracional, pois pede aos membros que acreditem sem evidência ou evidência suficiente. A religião pode ser explicada naturalmente, pois é um subproduto da evolução da espécie humana. E por fim, a religião tem efeitos maléficos sobre a política, o Estado, a educação, a sexualidade, a segurança etc.

O próprio título do livro - Deus, um delírio - é uma síntese do ponto fundamental da obra. Dawkins usa "delírio" ou "um delírio pernicioso" (ibidem, p. 56) em sentido técnico, no sentido de "crença ou impressão falsa" (DAWKINS, 2007, p. 28). Dawkins (2007, p. 58-61) exemplifica as crenças bizarras ou delirantes da religião cristã, como Jesus ser consubstancial ao Pai, a doutrina da Trindade, o panteão de santos e anjos com suas hierarquias, o apego de João Paulo II ao culto da Virgem Maria, principalmente de Fátima etc. Para nós, o título do livro de Dawkins parece se referir à obra Futuro de uma ilusão (1927), em que Freud sustentava a falsidade das crenças religiosas e buscava uma teoria para interpretar as crenças 
religiosas e sua origem. Contudo, no livro de Dawkins não há referência explícita ao livro do pai da psicanálise.

Dawkins (2007, p. 145) também alega, sustentado na pesquisa de Bell, que a crença religiosa está relacionada à inteligência. Segundo ele, quanto maior a inteligência ou a instrução de uma pessoa, menor a probabilidade de esta ter crenças religiosas. Uma das razões é que os religiosos sustentam crenças que contradizem fatos científicos demonstráveis, e isso diminuiria a plausibilidade de tais crenças (ibidem, p. 229).

No quinto capítulo, intitulado As raízes da religião, Dawkins pretende lançar bases para uma teoria que explique a religião como um fenômeno universal da espécie humana. Essa unidade está para além da cultura e da sociedade que a formam em seus aspectos mais superficiais. No seu aspecto profundo, parece a Dawkins, são a biologia e a teoria da evolução que podem nos fornecer a chave mais primitiva para essa tendência humana universal, e não as ciências sociais, que apenas completam o quadro.

Segundo a teoria de Dawkins (2007, p. 227), a religião deve ser vista como um subproduto de outra coisa. Por exemplo, a finalidade primitiva da sexualidade é a variação genética da espécie. Porém, a sexualidade foi tomando outras funções além dessa, como no caso de algumas espécies de mamíferos, pois tem uma importância na manutenção das relações sociais. Portanto, tentar compreender a religião simplesmente como uma adaptação para auxiliar a sobrevivência não seria o melhor modo de compreender a religião em termos biológicos. Em suas palavras: “A teoria geral da religião como subproduto acidental - um efeito colateral de uma coisa útil - é a que pretendo defender".

Dawkins (2007, p. 230-39) dá exemplos de possíveis produtos originais da crença religiosa. Por exemplo, há uma vantagem em crianças acreditarem sempre nos adultos sem questionamentos. Do mesmo modo, as crianças têm tendência para serem dualistas em relação à mente e ao corpo, bem como tendências para conceber a natureza teologicamente. Os ganhos de sobrevivência em termos de cérebros propensos a desenvolver essas ideias é que elas fornecem uma atitude para compreender a natureza de forma rápida e simplificada, dando às coisas a propriedade de serem intencionais, mesmo que não o sejam. Essa maneira de compreender as coisas é rápida e econômica.

Para explicar as diferenças e a evolução das religiões enquanto sistemas de crença, ele se utiliza do conceito de memes que, mutatis mutandis, seriam um tipo de genes transmitido culturalmente de um cérebro para outro. Assim, a teoria da religião de Dawkins (2007, p. 265) é concebida tendo dois elementos estruturantes: a teoria memética da religião e a teoria do 
subproduto psicológico. Contudo, não parece que Dawkins ofereça claramente uma hipótese que ele acredite que seja, de fato, o produto original do qual derivou a religião como subproduto. $\mathrm{O}$ que ele sustenta é que a religião é um subproduto, mas não define exatamente qual seria o produto primitivo do qual a religião teria se originado.

Em relação ao terceiro ponto - a afirmação de que a religião é um mal -, dele trataremos aos nos concentrarmos na moralidade e em outros pontos. Segundo Dawkins, a moral religiosa é um obstáculo para uma moralidade racional; um impedimento à ciência pela doutrinação e recusa das evidências; um entrave na política e numa legislação emperrada pelos preceitos religiosos.

Uma grande parte do livro Deus, uma ilusão é dedicada à moralidade. Um dos objetivos de Dawkins é mostrar que ser ateu não equivale a ser imoral. Igualmente de que a moralidade não implica um fundamento religioso, sobrenatural. No prefácio, o autor diz: “É possível ser um ateu feliz, equilibrado, ético e intelectualmente realizado" (DAWKINS, 2007, p. 23). Pede que os ateus "saiam do armário", assim como aconteceu com os homossexuais, pois não haveria "nada de que se desculpar por ser ateu. Pelo contrário, é uma coisa da qual se deve ter orgulho, encarando o horizonte de cabeça erguida, já que o ateísmo quase sempre indica uma independência de pensamento saudável, e mesmo um mente saudável" (DAWKINS, 2007, p. 26-27). Em suma, o ateísmo para Dawkins não é moralmente inferior ao teísmo, mas ao contrário, é superior.

No capítulo 6, As raízes da moralidade: por que somos bons?, Dawkins deseja desenvolver uma teoria da moralidade de modo semelhante a (e com as mesmas motivações de) uma busca de uma teoria biológica da religião. A moralidade igualmente seria um subproduto da evolução da espécie humana. É fácil, de um ponto de vista darwinista, explicar a contribuição, para a sobrevivência, da fome, do medo e do desejo sexual, no entanto é mais difícil explicar a compaixão (DAWKINS, 2007, p. 279). Em nível genético, parece claro, segundo Dawkins (2007, p. 280), que nossos genes são egoístas, mas será o mesmo no nível do organismo?

Segundo Dawkins (2007, p. 281-286), há vários tipos de altruísmo que são explicados pela teoria da evolução. Animais tendem a cuidar dos familiares para garantir que as cópias de seus genes sejam preservadas. Igualmente o altruísmo recíproco: se ajudar alguém em um determinado momento de privação, em outro momento menos promissor tenho alguém a quem recorrer. Outro caso é a vantagem de ter uma boa reputação. Há do mesmo modo na doação altruísta uma propaganda de dominância. Arriscar-se, dar alimento e outras ações 
mostram que o indivíduo é superior ao outro ou digno de dominá-lo. Em suma, "o que a seleção natural favorece são regras gerais, que funcionam na prática para promover os genes que as constroem" (DAWKINS, 2007, p. 287).

Por outro lado, o altruísmo, a generosidade, a compaixão etc. em nossa sociedade humana, de um ponto de vista biológico, é um subproduto ou erro, segundo Dawkins. De modo semelhante ao sexo, que tem por fim a procriação. O desejo de ter relações sexuais está profundamente enraizado em nosso cérebro, porém saber disso não compromete nossas relações sexuais ou as reduzem ao nível procriativo. São "equívocos abençoados e maravilhosos" (DAWKINS, 2007, P. 288). E mais: "Essas regras ainda nos influenciam, não de uma forma calvinisticamente determinista, mas filtradas pelas influências civilizadoras da literatura e dos costumes, da lei e das tradições - e, é claro, da religião" (ibidem, p. 289).

Um ponto importante sustentado por Dawkins (2007, p. 290-295) é a independência da moralidade em relação à religião. Um dos argumentos de Dawkins - baseado nas pesquisas do biólogo Marc Hauser, expostas no livro Moral minds: how nature designed our universal sense of right and wrong (2007) -, é de que as pessoas agem de modo semelhante em questões morais básicas, mas com pouca capacidade de dizer o porquê de agirem assim. A religião parece não ter um papel relevante na maioria de nossas ações, do ponto de vista moral. Em pesquisa conjunta, Hauser e o filósofo Singer chegaram à conclusão de que não há diferença entre as decisões morais de ateus e teístas, quando julgavam casos idênticos para os quais deveriam tomar uma decisão moral.

Dawkins (2007) oferece outros argumentos para mostrar que a crença em Deus não torna as pessoas moralmente melhores. Uma pesquisa feita por Gregory S. Paul sustenta que nações mais religiosas têm taxas maiores de homicídio, mortalidade juvenil, infecções por doenças sexualmente transmissíveis, gravidez de adolescentes, bem como abortos em relação às democracias prósperas, entre outros problemas, mas para nossos objetivos isso é o suficiente.

No capítulo 7, com o título O livro do "Bem" e o Zeitgeist moral mutante, Dawkins (2007, p. 305-359) pretende argumentar que a Bíblia, seja no Antigo ou no Novo testamento, de fato não é a base moral na qual se apoiam a maioria dos julgamentos morais. De fato, ambos os livros têm passagens que poucos tomam como sendo morais. Há, portanto, necessidade de princípio ou princípios para escolher quais das indicações bíblicas são morais ou não. Assim, não é a Bíblia em si que dirige as ações morais, pois esses princípios não são eles mesmos bíblicos. Além disso, defende que há um consenso moral entre as pessoas de 
uma determinada época (Zeitgeist). Esse consenso estabelece o que é mutável e não depende da religião para ser crido como moral ou imoral. Todavia, tal consenso encontra resistência do mundo religioso. Exemplificando, o consenso moral de nossa época pode ser sumarizado como: não provocar sofrimento desnecessário; ter o direito de livre expressão; pagar os impostos; não trair; não matar; não cometer incesto; aplicar a lei de ouro (DAWKINS, 2007, p. 339).

Para Dawkins (2007, p. 328-338), a religião tem causado muito mal aos seres humanos, entre eles a violência. Favorece a divisão em grupos fechados com uma identidade religiosa forte que mantém conflitos, por exemplo, o conflito na Irlanda entre católicos e protestantes, ou entre hindus e islâmicos na Índia. As religiões são pouco abertas à ideia de casamentos entre pessoas de credos diferentes (DAWKINS, 2007, p. 337-338).

É principalmente no oitavo capítulo, O que a religião tem de mau? Por que ser tão hostil?, e no nono, Infância, abuso e a fuga da religião, que se concentram as consequências imorais atribuídas por Dawkins à religião. Um dos pontos destacados é que as religiões fundamentalistas não apoiam a ciência. "Como cientista, sou hostil à religião fundamentalista porque ela debocha ativamente do empreendimento científico" (DAWKINS, 2007, p. 364). Ela arruína a educação de muitas crianças e jovens com a confiança de que "a fé inquestionável é uma virtude" (DAWKINS, 2007, p. 367).

Para o zoólogo de Oxford, a religião também ameaça os homossexuais, até com a pena de morte; o absolutismo religioso penetra todos os aspectos da vida humana. Há o desejo de regular o que as pessoas adultas fazem na esfera privada, como no caso do Talibã. De modo semelhante, alguns cristãos querem aplicar as regras morais do Antigo Testamento para os casos de moral sexual, como em relação à homossexualidade e à infidelidade conjugal (DAWKINS, 2007, p. 370-374).

Para Dawkins, a religião impede o avanço da medicina, dando o status de pessoa a um conjunto de células, fazendo com que indivíduos sofram na espera de soluções que poderiam vir de certas pesquisas e, além disso, equipara a destruição de células de alguns dias com o assassinato de um ser humano adulto. Ademais, impede que adultos possam decidir interromper a vida em situações de iminência da morte por doenças terminais.

Concordando com Harris, Dawkins (DAWKINS, 2007, p. 392) sustenta que a religião moderada ajuda o extremismo, pois crenças absurdas auxiliam a consecução de ações atrozes, como no caso de mártires (homens-bombas) conseguirem o Céu. 
Dawkins acusa a religião de abusar não só fisicamente das crianças, no caso da pedofilia; pensa não ser o pior e até acha que nesse caso é excessivo o ataque à Igreja Católica. Sua crítica se dirige ao abuso mental do "implante" da fé na cabeça das crianças. Em suas próprias palavras: "por mais horrível que o abuso sexual sem dúvida seja, o prejuízo infligido pela atitude de educar a criança dentro da religião católica [é maior]”. Ideias como a do inferno criam traumas dificilmente superáveis, mesmo quando essas crianças ficam adultas (DAWKINS, 2007, p. 405).

No campo da política, Dawkins (2007, p. 369-370; 321) ataca principalmente a direita cristã, que chama de "Talibã americano" e "teocracia incipiente". A interferência da moral cristã dos dez mandamentos na república americana é lamentável. A religião tem um forte poder nos Estados Unidos, de forma que um candidato a presidente que admitisse ser ateu cometeria um suicídio político (DAWKINS, 2007, p. 73). A religião também mantém correlação negativa com o liberalismo político (DAWKINS, 2007, p. 144).

No caso do gênero, a mulher é vista como inferior pela religião fundamentalista. A mulher deve ser submetida aos pais e depois ao marido. Nas palavras de Dawkins (2007, p. 458):

\footnotetext{
Um dos espetáculos mais tristes de nossas ruas hoje em dia é a imagem de uma mulher coberta por uma forma negra dos pés à cabeça, espiando o mundo através de uma nesga minúscula. A burca não é só um instrumento da opressão de mulheres e de repressão de sua liberdade e de sua beleza; não é só um símbolo da crueldade flagrante masculina da trágica submissão feminina.
}

No caso do fundamentalismo cristão, Dawkins (2007, p. 372) cita como exemplo de submissão feminina as palavras de Pat Robertson, fundador da Coalizão Cristã: "Sei que é doloroso para as mulheres ouvirem, mas, se você se casa, aceita a liderança de um homem, seu marido. Cristo é o chefe do lar e o marido é o chefe da mulher, e é assim que as coisas são, ponto final".

\section{DANIEL DENNETT: QUEBRANDO O ENCANTO: A RELIGIÃO COMO FENÔMENO NATURAL}

O professor universitário Daniel Dennett (nascido em 1942), conforme Richard Gillian (2008, p. 39-40), graduou-se na Universidade de Harvard em 1963 e recebeu o doutorado pela Universidade de Oxford em 1965. É codiretor do Centro para Estudos Cognitivos da Tufs 
University. Durante quarenta anos de pesquisas, fez contribuições nos estudos sobre a consciência, a psicologia do desenvolvimento, a inteligência artificial, a teoria da evolução, a filosofia da mente, entre outras áreas. Seu livro mais importante no campo da religião é Quebrando o encanto: a religião como fenômeno natural (2006).

Quebrando o encanto (DENNETT, 2006, p. 16-17) é divido em três partes. A primeira é dedicada a argumentar e defender a possibilidade de estudar a religião como um fenômeno natural. Na segunda parte, pretende-se desenvolver um relato sobre as origens da religião, e no último capítulo (a terceira parte), analisar a religião presente e averiguar se a crença religiosa é moralmente importante para o indivíduo e para a sociedade. As palavras "quebrando o encanto" do título são assim retomadas: "o encanto que eu digo que deve ser quebrado é o tabu contra uma pesquisa direta, científica e sem obstáculos dos segredos da religião como fenômeno natural" (DENNETT, 2006, p. 28)

No prefácio, Dennett (2006, p. 7-10) chama a atenção do leitor de que ele está escrevendo um livro no contexto dos Estados Unidos, onde o clima intelectual não é unanimemente favorável ao estudo da religião como um fenômeno natural. Os adversários dessa abordagem são principalmente religiosos, mas também cientistas sociais que pensam que a religião é um fenômeno tipicamente social, e as ciências naturais, como a biologia, não têm nada com que contribuir para o entendimento desse objeto social.

$\mathrm{Na}$ primeira parte, intitulada Abertura da caixa de Pandora, Dennett pretende justificar e defender o estudo científico da religião como fenômeno natural. Ele se diz vinculado ao empreendimento do filósofo David Hume, que sustentava o estudo sobre a religião de duas maneiras, uma buscando fundamentar a religião a partir das razões e a outra estudando a religião como um fenômeno natural. Nesse contexto, "natural" é utilizado no sentido de ser sua explicação de cunho não sobrenatural. Porém, Dennett sustenta que a princípio isso não implica que estudar a religião como fenômeno natural elimine a possibilidade de ela ser igualmente causada por um agente sobrenatural. Em suas palavras:

Posso querer dizer que a religião é natural como oposta ao sobrenatural, que é um fenômeno humano composto de eventos, organismos, objetos, estruturas, padrões e coisas parecidas que obedecem, todos, às leis da física ou da biologia, e que portanto não envolve milagres. E é isso que quero dizer. Note que pode ser verdade que Deus exista, que Deus seja mesmo o criador inteligente, consciente e amoroso de todos nós, e, no entanto, ainda assim, a religião em si, como um conjunto complexo de fenômenos, é perfeitamente natural (DENNETT, 2006, p. 35-36). 
Em relação à busca das razões para a existência de Deus, Dennett (2006, p. 249) diz que "é em grande escala um esforço desperdiçado". Sustenta que tanto as alegadas verdades históricas da religião como os argumentos filosóficos, tais como o ontológico, o cosmológico (Causa Primeira) e o do projeto enfrentam sérias objeções (DENNETT, 2006, p. 256-261) para serem considerados bons argumentos a favor da divindade. Em suma, são falazes.

Dennett (2006, p. 19) define religião (mesmo sabendo dos riscos de uma primeira tentativa que não se pretenda fechada a contraexemplos) como um "sistema social cujos participantes confessam a crença em um agente ou agentes sobrenaturais cuja aprovação eles buscam". Em relação ao conceito de Deus, as religiões abraâmicas contêm um conflito entre a imagem de Deus como um ser eterno, onipotente, onisciente, espírito etc., e Deus como agente que, por exemplo, escuta as nossas preces. O conflito se estabelece por sustentarem duas imagens opostas, uma imagem antropomórfica da divindade e outra de um ser necessário. A religião monoteísta integra ambas, mesmo que esteja além da razão compreender como se articulam (DENNETT, 2006, p. 19-20).

Ele volta a tratar sobre o conceito de Deus no capítulo oitavo (DENNETT, 2006, p. 215-262) e no décimo primeiro, no tópico Algumas vias a serem exploradas: como podemos nos centrar nas convicções religiosas? (DENNETT, 2006, p. 333-340). Dennett desenvolve a ideia de que, para muitos, Deus não é um objeto intencional que tem uma referência num ser real; eles têm apenas crença no objeto intencional (que está na mente do sujeito).

A maioria dos crentes crê na crença em Deus. Crer na crença em Deus é algo de que até um ateu é capaz $\mathrm{O}$ conjunto dos que acreditam em Deus implica que também acreditam na crença em Deus, por isso há muito mais gente que acredita na "crença na crença" (DENNETT, 2006, p. 238) do que na existência de Deus. Os motivos da crença na crença em Deus seriam, por exemplo, a possibilidade de ação; o fundamento da moral; e o proporcionar o sentido absoluto da vida. Mesmo se Deus de fato não existe, é bom termos a crença na crença de sua existência. Como ele próprio diz (DENNETT, 2006, p. 217):

\footnotetext{
A crença na crença de que alguma coisa é importante tornou-se compreensivelmente forte e amplamente disseminada. A crença no livre-arbítrio é outra visão protegida com vigor pelos mesmos motivos. Aqueles cujas investigações parecem pôr essas crenças em risco muitas vezes são deturpados, deliberadamente, para [se] desacreditar aquilo que parecer ser uma tendência perigosa.
}

Mas por que estudar a religião cientificamente? Sumariamente, para Dennett (2006, p. 44-63) a religião é algo importante que influencia e vai continuar a influenciar o mundo 
(DENNETT, 2006, p. 59). É algo importante e devemos saber mais sobre ela. Esse conhecimento a respeito da religião não apenas sacia nossa curiosidade, mas nos capacita a saber como funciona. Isso possibilita à sociedade agir de modo eficaz e controlar os excessos da religião. Não podemos fugir dessa obrigação cognitiva e moral.

Todavia, por que existe a resistência de se estudar a religião como um fenômeno natural? Segundo Dennett (2006, p. 28), umas das motivações é o medo de colocar a religião sob o escrutínio da ciência. Outro é que a ciência ocidental seria ruim para alguns críticos radicais da ciência (DENNETT, 2006, p. 50). Além disso, o estudo da religião é possivelmente muito aberto à interferência dos motivos pessoais do pesquisador - ou se deseja defender a religião das críticas ou demonstrar a irracionalidade da crença religiosa. Essas atitudes também prejudicam as pesquisas em religião. Mas são felizmente evitáveis (DENNETT, 2006, p. 42).

Na segunda parte do livro, a mais extensa, composta de cinco capítulos (4-8), o autor se propõe a dar pistas de uma teoria, com fundamentos na biologia, que pode explicar a religião e não apenas propiciar "uma satisfação prematura da curiosidade", como as explicações fornecidas pelas ciências humanas até agora o fizeram. Explicações como a razão de ser da religião serviriam apenas para confortar o crente; explicar ou encorajar as pessoas ou grupos; proporcionar a cooperação de grupo (DENNETT, 2006, p. 114-115). Uma explicação que dê realmente conta dos mais profundos princípios da religião deve levar em conta a biologia e, em particular, a teoria da evolução. O teórico não deve ter medo de se intrometer em um assunto que seria território das ciências do espírito. Deveríamos ir contra o antidarwinismo presente nas ciências sociais e humanas, que sustentam haver um abismo entre ambas (DENNETT, 2006, p. 202).

Longe de querer dar um resumo amplo da teoria, pois não é esse nosso objetivo, podemos sintetizar a teoria das origens da religião de Dennett (2006) do modo explicitado a seguir. A teoria de Dennett da religião é forjada em suas pesquisas sobre a intencionalidade. Uma noção importante é a de base racional descomprometida. É mais fácil compreender esse conceito por meio de um exemplo. Uma rã tem a seguinte disposição: “objetos grandes em movimento, fugir; objetos pequenos em movimento, engolir”. Não que a rã tenha consciência desse processo, mas executa isso instintivamente, pois esse comportamento foi selecionado. $\mathrm{E}$ esse comportamento racional não consciente faz a rã atingir o objetivo de manter-se viva e reproduzir. Em suma, a base racional descomprometida estabelece que algum animal ou 
processo são racionais no sentido de atingir seus objetivos, mesmo sendo o agente e o próprio sistema que o produzem inconscientes do complexo mecanismo que gerou suas rotinas.

Outro conceito importante de Dennett, que ele desenvolveu em seus estudos em filosofia da mente, é que os animais superiores desenvolveram um "bom estratagema", como a chamada postura intencional. Esses animais tratam outras coisas como sendo agentes, que possuem crenças, desejos e racionalidade (o melhor modo de conseguir seus objetivos). E o animal em foco aqui é o Homo sapiens.

Dennett supõe que, munidos desse conceito de postura intencional e do conceito de base racional descomprometida, os seres humanos não são simples seguidores da base racional descomprometida, que é a fonte cega de muitos comportamentos de micróbios, vegetais e animais. O ser humano usa a postura intencional para conduzir, compreender, explicar e predizer o comportamento de outros animais e do próprio mundo inanimado. $\mathrm{O}$ desenvolvimento desse mecanismo ganha uma dimensão extraordinária, pela capacidade da linguagem que o habilitou a desenvolver uma psicologia popular para interpretar o comportamento de outros seres.

Mas como entra a religião nesse contexto teórico dennettiano? O ser humano tem uma tendência muito forte de usar a postura intencional até em contextos nos quais essa estratégia não funciona muito bem. Essa capacidade de atribuir agência faz com que a atribuamos a todas as coisas que se movem, como ocorre no caso do animismo. Tudo possui alma, espírito. E mesmo que as coisas que se movem não sejam as suas reais fontes, há outros seres invisíveis que lhes dão movimento, como os deuses da chuva que movem as nuvens. De modo semelhante temos os deuses da saúde, da fertilidade, bem como os maus, da doença, da guerra etc. A religião teria, portanto, sua origem nessa capacidade ou estratégia usada de modo excessivo.

Como ser linguístico e social, o ser humano não passa às gerações seguintes apenas o que contém em seus genes, mas informação que se replica nos cérebros dos indivíduos; essa informação é o que Dennett chama de memes, conceito cujo pai é Dawkins, como já vimos. Os memes são a contraparte cultural da parte puramente genética, que são os genes. A religião é um conjunto de crenças, e essas são passadas mimeticamente às outras gerações.

Dennett (2006) separa duas fases da religião. A primeira fase é da religião popular ou do povo - "o tipo de religião que não tem credos escritos, teólogos, nem hierarquia ou funcionários. [possui] (...) rituais, histórias a respeito de deuses ou ancestrais sobrenaturais, práticas proibidas e obrigatórias" (ibidem, p. 153). Nessa fase pouco reflexiva e organizada, a 
religião está centrada nas adivinhações para se decidir o que fazer, nos xamãs que garantem a saúde.

O culto dos antepassados tem um papel importante nas sociedades nômades. Para Dennett (2006, p. 140s), uma possibilidade de explicação, além das especulações de Freud e Nietzsche, é de que em nossa espécie, como em outras, os pais têm um vínculo muito estreito com os filhotes, que deles necessitam muito para sobreviver (espécie nidícola). Essa seria a base para o culto dos antepassados, que foi exaptada desse vínculo mais primitivo.

A segunda fase da religião é a da religião organizada. Dennett (2006, p. 182) postula que o surgimento provável da religião organizada ocorreu com o aparecimento da agricultura. É uma grande revolução no estilo de vida das pessoas. A religião se torna reflexiva, muito complexa em sua teologia, nos seus ritos. É a época da intendência. Há pessoas inteligentes que são responsáveis pelos memes até agora pouco domesticados. Nas palavras de Dennett (2006, p. 184-185):

\footnotetext{
O que pretendo sugerir agora é que, na mesma época da domesticação de animais e plantas, houve um processo gradual no qual os memes selvagens (autossustentáveis) da religião popular se tornaram inteiramente domesticados. Eles adquiriram intendentes. Os memes que têm a sorte de ter intendentes, pessoas que irão trabalhar arduamente e usar a inteligência para promover a propagação deles e protegê-los de seus inimigos, são aliviados de grande parte da carga de manter a existência de sua própria linhagem.
}

Dennett (2006) sustenta que, com a religião domesticada ou organizada, a transmissão teve profundas revisões, e os intendentes tornaram a religião em parte um segredo; desenvolvem-se imposturas e também as crenças religiosas se tornam invulneráveis à refutação. As vantagens da religião (cui bono?) também mudaram. Há alianças entre líderes políticos e sacerdotes - como na asserção de que os governantes são divinos, por exemplo -, usando-se a religião para aumentar poder e fortuna (ibidem, 2006, p. 186).

Na terceira parte, Dennett (2006, p. 265-377) se deterá nas questões práticas e atuais da religião. Ele vai atacar a ideia de que ser uma pessoa moral depende da religião, bem como a tese de que sua fundamentação racional depende da religião, além das razões que possa fornecer às suas crenças e ações morais.

Outro ponto é a questão de o significado da vida ou finalidade da vida ser dependente da religião. A vida de uma pessoa não crente está fadada a ser imoral e sem sentido? Dennett contestará essas alegações, asseverando que um não crente pode ter uma vida rica e feliz. 
Em relação à moralidade, argumentará que, no concernente à vida moral de pessoas crentes ou não, dados empíricos que temos a respeito não sustentam haver diferenças significativas. Ademais, uma moral aceita com base apenas numa revelação religiosa sem base racional deve ser vista como perigosa fonte de fanatismo. Irá tratar também das toxidades da religião, porém não negará que ela pode trazer benefícios pessoais e sociais.

Em relação ao bem da religião, Dennett (2006, p. 267-268) sustenta que a paixão religiosa criou obras de arte maravilhosas, como Alhambra, as mesquitas de Isfahan, Istambul, entre outras. O cristianismo, a Hagia Sofia e as catedrais europeias. Os budistas, hindus e xintoístas, seus maravilhosos templos. Na música, temos Bach, Händel e as cantigas de natal. Igualmente, lindas histórias e cerimônias. Em relação às boas ações, há uma longa história de alívio do sofrimento, da dor, do cuidado dos doentes, da companhia. Além disso, algumas pesquisas indicam que a religião faz bem à saúde do indivíduo (DENNETT, 2006, p. 288ss.). Em suas palavras (DENNETT, 2006, p. 269): "Há muito do que os amantes da religião podem se orgulhar, em suas tradições, e muito pelo qual nós todos podemos ficar gratos". Contudo, o amor é cego e deve ser questionado. A religião é culpada de violência, fanatismo e abuso (DENNETT, 2006, p. 272-274). A religião é, portanto, um misto de coisas boas e ruins.

\section{CHRISTOPHER HITCHENS: DEUS NÃO É GRANDE: COMO A RELIGIÃO ENVENENA TUDO}

Chistopher Hitchens nasceu em 13 de abril de 1949 em Portsmouth, na Inglaterra. É formado pela Balliol College da Universidade de Oxford em filosofia, política e economia. Trabalhou para vários jornais e revistas. Os temas de seus escritos eram religião, arte, política, guerra e literatura. Escreveu dezessete livros. Para nós, o livro mais significativo em relação a suas ideias a respeito da religião é God is not great: how religion poisons everything, de 2007. Hitchens mudou-se para os Estado Unidos em 1981. Uma das tragédias de sua vida foi o suicídio de sua mãe. Morreu de câncer em 15 de dezembro de 2011 em Houston, Texas.

Deus não é grande é dividido em dezenove capítulos. Nos agradecimentos, o autor afirma que esteve escrevendo esse livro durante "toda a vida" (2008, p. 13). Diz que os ateus, como Dawkins, Gould e Dennett, representam posições ateístas diversas, sustentadas argumentativamente pela razão e pela ciência, mas não por fundamentalismo. E cita o seu desacordo em se chamar os ateus com o nome de "brilhantes" (2008, p. 19). É nesse espírito 
de reflexão crítica que escreve o livro, ao contrário do que diz ser o modo de agir dos religiosos e da religião.

O ataque à religião é o ponto central na obra de Hitchens (2008). A religião é uma invenção humana (HITCHENS, 2008, p. 25). Ela não serve como guia moral, pois a arte tem contribuições muito melhores a oferecer do que o Antigo e Novo Testamento, por exemplo. A moral não depende da religião, que origina e permite muitos males que aconteceram e acontecem no mundo. Tudo o que a religião pode ter trazido de bom é, em nossos dias, dispensável. Hitchens afirma que a religião é coisa do passado, embora não acredite que um dia a religião desapareça da sociedade, pois temos medo de morrer, do que não conhecemos, das misérias etc. (HITCHENS, 2008, p. 28). Somos seres frágeis. É inegável, todavia, que a religião tem trazido muito sofrimento à humanidade (HITCHENS, 2008, p. 227-238).

Critica as religiões por estas se intrometerem na política para defesa de suas posições religiosas, seja na moral, na educação, na organização do Estado etc., impondo aos outros suas pretensões (HITCHENS, 2008, p. 31). Explora como as várias religiões, seja o judaísmo, o cristianismo, o islamismo, o budismo, o hinduísmo ou o confucionismo, se unem ao poder político para ter vantagens, e é sabido que essa união se deu com governantes como Stalin, Mussolini, o imperador do Japão, entre outros. A religião uniu-se e ajudou a fortalecer sistemas de governo que cometeram cruéis assassinatos (HITCHENS, 2008, p. 29-52; p. 195216).

$\mathrm{O}$ ataque à religião e seus malefícios são pintados no livro de Hitchens quase à exaustão do leitor. Uma grande parte do livro consta da narração desses fatos terríveis, alguns deles vividos muito de perto pelo autor, enquanto jornalista.

As religiões são constituídas de muitas superstições, como submeter os fiéis a determinadas dietas, a crenças infundadas (as "72 virgens" para mártires); interferir nos tratamentos de saúde, por exemplo, não deixando as meninas tomarem vacinas para o HPV, porque a doença previne a depravação sexual; ou defender a inutilidade e o não uso do preservativo, como feito pelo cardeal Alfonso Trujillo.

Hitchens continua em várias páginas de seu livro elencando atos que considera males da religião. A aids é vista por grupos fundamentalistas protestantes como castigo de Deus contra os homossexuais. A crença dos mórmons contra a transfusão de sangue deixa pessoas que poderiam se curar morrerem. Pastores professam crenças absurdas sobre o fim do mundo, além do desejo pelo fim (HITCHENS, 2008, p. 53-73). Crianças são submetidas à 
doutrinação e a crenças absurdas, como a da condenação eterna e da existência do Demônio, que causam malefícios psicológicos permanentes (HITCHENS, 2008, p. 239-250).

A religião é uma fonte de mal para as mulheres e crianças. Citem-se o drama das mulheres submetidas no Islã; de menores e jovens sujeitos aos abusos de sacerdotes e religiosos católicos; o sofrimento das crianças e o risco de infecções e morte nos rituais da retirada do prepúcio entre os judeus. Na África, a circuncisão feminina também leva a esses problemas, e é um insulto à condição da mulher. O casamento, seja no Irã ou na Índia, de crianças com apenas nove anos.

A religião é uma fonte da repressão sexual e culpada de incutir nas crianças e nos adolescentes ideias errôneas acerca da sexualidade. Igualmente os homossexuais são mortos e submetidos pelos ditames da religião. As maiores vítimas são as mulheres e crianças, pois a religião é uma invenção não só humana, mas tipicamente masculina (HITCHENS, 2008, p. 62-76).

Depois dos quatro primeiros capítulos, Hitchens, argumentando sobre os malefícios da religião, dá assim sentido ao título de seu livro, que seria até mais adequado, segundo nosso ponto de vista, denominar-se "As religiões não são grandes". Hitchens não tem uma visão positiva de Deus, ou melhor, do conceito de Deus, o "perverso Deus do monoteísmo”.

No quinto capítulo, ele se volta às bases cognitivas da religião, a saber, a fundamentação racional da crença em Deus. Mesmo o Deus do Novo Testamento não é moralmente superior ao do Antigo. O segundo manda matar o povo que habita a terra que Deus dá a Israel. O primeiro, o Deus de Jesus, condena as pessoas que não lhe obedecem ao inferno para toda a eternidade. Ambos são maus e cruéis.

No mesmo capítulo, argumenta que as alegações metafísicas das religiões são falsas. Os fundadores das religiões têm uma visão primitiva e ultrapassada do mundo e do ser humano (HITCHENS, 2008, p. 80). A religião é uma fonte permanente de ignorância. Há muito pouco para aprender com elas em sua milenar história (HITCHENS, 2008, p. 85). Compartilha com Dawkins e outros a asserção de que Deus não é uma boa explicação das coisas, pois só transferimos o problema para saber quem criou Deus (HITCHENS, 2008, p. 86-88).

Dedica o capítulo sexto ao argumento do projeto ou do desenho (design). Utiliza-se aqui das ideias das ciências biológicas, e principalmente das de Darwin, para mostrar que a explicação mais simples da aparente teleologia é o processo de seleção natural. 
Nos capítulos 7, 8 e 9 (HITCHENS, 2008, p. 115-158), ataca a revelação divina sustentada pelo judaísmo, cristianismo e Islã nos livros do Antigo e do Novo Testamento, e no Corão. A revelação por parte de Deus seria evidência e fonte de conhecimento para a religião, bem como para alegar sua base racional. O primeiro problema é o pluralismo de revelações. Quem está certo? Depois, a dependência do cristianismo e principalmente do Islã em relação à revelação das religiões que a precederam, o judaísmo e igualmente o cristianismo. Os historiadores mostram como esses livros são uma mistura de várias doutrinas e de escolhas arbitrárias. Além, claro, de conterem muitos erros factuais, contradições e encerrarem uma moral problemática. Em suma, os livros das religiões não são fontes confiáveis, quer como base para a informação fidedigna, quer para a orientação moral.

No capítulo 10, Hitchens (2008, p. 159-174) se volta para o último bastião da alegação da verdade das religiões - os milagres. Primeiramente, chama a atenção que os religiosos usam os milagres para impressionar os incautos, seja a subida de Maomé aos céus por meio de seu "cavalo" Buraq, um tipo de burro-mula de asas, ou numa viagem entre Meca e Jerusalém; a levitação de místicos cristãos etc. Hitchens utiliza o argumento de Hume contra os milagres, alegando que são contra a experiência e, portanto, são improváveis para aqueles que não os viram e recebem a informação por testemunho. Há também fraudes em supostos milagres.

Em relação aos milagres do Novo Testamento, há vários problemas que foram apontados por historiadores do cristianismo primitivo em relação à confiança das fontes dos escritores desse livro. Em suma, é mais simples e racional (navalha de Ockham) explicar os milagres de modo natural do que apelar para uma explicação sobrenatural que dê apoio cognitivo às religiões.

Em suma, nesses capítulos (7 a 9) dedicados à discussão dos argumentos racionais a favor da religião, conclui que estes não são suficientes, e a religião é um conjunto de alegações sem fundamento. Os argumentos são falazes. Portanto, não é racional acreditar nas alegações das religiões.

Os capítulos 11 e 12 (HITCHENS, 2008, p. 175-194) exploram as origens da religião. O método é o seguinte: "se observamos o processo de formação de uma religião podemos formular algumas hipóteses sobre as origens daquelas religiões que foram criadas antes [de] (...) a maioria das pessoas" saberem ler. Hitchens faz uma análise das religiões do "culto à carga" melanésio, da Igreja pentecostal Marjoe e da Igreja de Jesus Cristo dos Santos dos Últimos Dias (Mórmons). Sustenta que as religiões têm um começo permeado de interesses nada celestiais, mas humanos e financeiros. E que há em seus inícios pessoas diretamente 
comprometidas com a religião nascente que sabem que ela não é verdadeira e, portanto, não acreditam, contudo se beneficiam com a manutenção das crenças.

Do capítulo 13 ao 19, Hitchens argumenta que a religião não é a fonte da moral e que o comportamento moral não necessita da religião. Dá vários exemplos de homens e mulheres de várias religiões que têm um comportamento imoral. E alguns religiosos que têm um comportamento moral elevado, porém suas crenças morais não dependem diretamente de suas crenças religiosas, e até vão contra a moralidade estabelecida ou a da maioria dos integrantes daquela religião num dado momento. Hitchens examina o caso de Martin Luther King. Pessoalmente, não era nenhum santo no sentido religioso tradicional, ademais tinha amantes. Superou o racismo em prol de uma visão libertária e de igualdade racial. Até poderia se expressar em linguagem religiosa, mas suas motivações eram de ordem racional.

Não há como logicamente relacionar se quanto mais devoto e religioso alguém é mais ético será, igualmente se quanto menos religiosa, também menos moral seria uma pessoa. Barbaridades são e foram justificadas pelas religiões, como são os casos do racismo e da submissão feminina. Gandhi tinha ideias retrógradas que, se fossem efetivadas, teriam consequências muito ruins para os indianos. Os assassinatos de Sadam Hussein eram justificados por ele por meio do Corão. No capítulo 14, o autor sustenta que as religiões orientais, como o budismo, o confucionismo ou o hinduísmo, não devem ser vistas como melhores que o monoteísmo abraâmico. Corrupção, assassinatos, monges parasitas da sociedade, apoio aos regimes totalitários estão presentes nas religiões orientais como estão nas ocidentais (HITCHENS, 2008, p. 217-226). Em suas palavras, em relação ao budismo: "Um credo que despreza a mente e a liberdade individual, que predica a submissão e a resignação e que considera que a vida é uma coisa tão passageira e desgraçada está mal equipado para a autocrítica" (HITCHENS, 2008, p 226).

\section{BUSCANDO UMA DEFINIÇÃO DE "NEOATEÍSMO"}

Quando falamos de definição, entendemo-la de vários modos. É comum entender uma definição como a atribuição de propriedades necessárias e suficientes (definiens) ao objeto que está sendo definido (definiendum). Um tipo de definição dessa espécie não nos parece uma boa estratégia para compreendermos o que é neoateísmo. Portanto, não estaremos oferecendo uma definição de tipo explícita. Por quê? Isso demanda uma resposta um pouco complexa. 
Em primeiro lugar, concordamos, com aqueles que defendem, como Thomas Zenk, que o neoateísmo é uma criação da mídia, pois de fato não há novidade teórica, porém entendemos que há uma ligação profunda entre os neoateístas.

Essa ligação se fundamenta num intercâmbio de ideias muitíssimo semelhantes entre eles, dado que são leitores uns dos outros. Sam Harris leu muitas obras de Dawkins e de Dennett; Dawkins, por sua vez, leu as obras de Harris e de Dennett; por seu turno, Dennett leu as obras de Harris e Dawkins, e Hitchens conhece a obra de todos eles. Nossa hipótese é que quem deu o tom à discussão foi Dawkins, reforçado pelas obras que se seguiram dos outros membros neoateus.

Os livros, a temática e mesmo a estrutura do pensamento desses autores são muito semelhantes, e não por acaso. Mesmo quando defendem ideias com que não são concordes, são poucas e quase sempre em detalhes. O que cada um deles está fazendo é completar o livro dos anteriores em pontos nos quais pode contribuir para esse diálogo. É um modo simples de compreender a grande semelhança não só na temática, mas nas referências até das mesmas citações que se encontram nas obras. Não é plausível ser simples coincidência. Dawkins completa a discussão de Harris fundamentalmente na refutação das provas tradicionais da existência de Deus, algo em que Harris não se detém, dado que está mais interessado na tese geral de a religião se pautar na crença sem fundamentos (fé). Por sua vez, Dennett desenvolve uma teoria da religião com fundamento na biologia e Dawkins a corrobora a respeito dos primórdios da religião. A própria teoria de Dawkins apoia-se nas elaborações dennettianas. É difícil dizer se em todos os detalhes, mas ambas concordam que a religião é um subproduto evolutivo. Christopher Hitchens preenche a lacuna com o estudo quase etnográfico de casos da maldade e da violência da religião, cobrindo a maioria das religiões ocidentais e orientais.

Esses livros estão dialogando conscientemente uns com os outros. O que não é plausível é que tenha havido um propósito comum de que eles viessem a ser produzidos intencionalmente com base em um acordo entre os autores e editoras. Não temos evidências para alegar isso. O que temos é a afirmação de Hitchens, em junho de 2007, sentindo-se honrado quando associado com Dawkins, Dennett e Harris (GILLILAN, 2008, p. 39). Os quatro, a partir dessa associação, são chamados de os quatro cavaleiros do ateísmo (horsemen of the counter-apocalypse).

Em relação a "neoateísmo", trata-se de um termo dado pela mídia, não sendo por eles utilizado sequer uma vez nos textos analisados. Há um texto de Dennett em que ele parece (não é incontestável essa interpretação, pois o texto não é claro) fazer uma diferença entre o 
velho ateísmo e o novo ateísmo. O novo ateísmo seria aquele pós-Darwin, que tem a possibilidade de argumentar de modo mais convincente do que se fez no passado contra o teísmo, apelando-se à teoria da evolução. Os "quatro cavaleiros" apenas se denominam ateus, e até, no caso de Dennett e Dawkins, de "brilhantes" (bright), mas nenhum se autodeclara "neoateu".

O neoateísmo também não se constitui de um grupo fechado, com apenas esses quatro membros. Outros homens e mulheres são associados ao movimento. Quando da morte de Hitchens, uma mulher, Ayann Hirsi Ali, assumiu a posição de "cavaleira", mas muitos outros são associados ao grupo. Dada essa pluralidade de pessoas e igualmente de posições, bem como a possível abertura para o acolhimento de mais participantes sob a mesma denominação, é muito mais adequado entender o neoateísmo como uma família. Numa família é possível haver muitos membros que se assemelham, mas não são em todos os seus aspectos iguais; fenômeno semelhante ocorreria no neoateísmo. Os membros têm coisas comuns entre si e, possivelmente, há semelhanças que apenas alguns apresentam, em certos aspectos, mas nem todos as possuem.

No início, estabelecemos alguns conceitos que seriam guias para nossa comparação entre as obras fundantes do neoateísmo. São eles: Deus (D), religião (R), moralidade (M), sociedade $(\mathrm{S})$, política $(\mathrm{P})$, educação $(\mathrm{E})$, ciência $(\mathrm{C})$, Estado $(\mathrm{E})$, gênero/sexualidade $(\mathrm{G})$. Sobre esses tópicos, vamos estabelecer as teses do neoateísmo que nos parecem comuns a todos, e assim sintetizar o movimento como um conceito aberto, um conceito por "semelhança de família". Vejamos a seguir.

Tese D: as crenças em Deus ou em deuses são invenções humanas (naturais). Não há evidência filosófica, científica ou empírica para justificá-las. As crenças em Deus ou nos deuses são frequentemente imorais, e as ações advindas dessas crenças são violentas.

Tese R: a religião é um fenômeno natural e social. Uma explicação da religião não superficial deve levar em conta a teoria da evolução como uma ferramenta explicativa da religião como fenômeno natural. A religião não é uma virtude nem cognitiva e nem moral, pois se baseia na fé (crer em algo sem evidências suficientes) e em mandamentos primitivos, cruéis e irracionais. A religião deve ser um assunto privado.

Tese I: reação aos atentados do terrorismo islâmico ao World Trade Center.

Tese M: a moralidade é independente da religião. A moralidade é fundamentada na natureza, na razão, na ciência, e não na religião. Alguém ser bom não implica que seja 
religioso, e vice-versa. A moralidade da religião é primitiva e as ações de muitos religiosos são imorais (aquelas baseadas nos próprios preceitos da religião).

Tese S: a sociedade não precisa mais da religião; tanto as explicações religiosas como a moralidade das religiões estão ultrapassadas pela ciência e pela cultura hodierna (sentimentos, arte, Zeitgeist). A unidade da sociedade não depende hoje em dia da religião, mas de outros mecanismos sociais, econômicos, políticos, e não mais religiosos. A religião, ao contrário, tem sido a causa de separação, segregação e conflito.

Tese P: a política e os políticos devem ser autônomos nas decisões em relação à religião. Os governantes não devem usar a política para defender os interesses religiosos ou das religiões. E a opção religiosa dos políticos deve ser privada, e não organizada como fonte para o exercício de poder religioso na elaboração, na execução e na justiça de acordo com os cânones religiosos.

Tese E: a educação deve ser baseada na razão e na experiência e não em dogmas religiosos ou em teorias religiosas. A religião não deve ditar o que deve ser ensinado nas escolas em matéria científica para que se acomode às crenças teológicas. As crianças deveriam ser protegidas, de alguma maneira, dos dogmas religiosos.

Tese C: a ciência e o pensamento científico devem ser ensinados e divulgados nas sociedades. A educação científica é fundamental no combate ao obscurantismo. As concepções inconsistentes com a ciência ou com a razão não devem ser cridas.

Tese T: o Estado tem que ser independente da religião. A religião não deve usar o Estado em seu benefício. As leis devem ser independentes dos dogmas religiosos.

Tese G: todas as pessoas são iguais perante a lei, sejam mulheres, crianças, homossexuais. Todas as etnias (bem como todas as religiões) são iguais perante a lei. O homem não é superior à mulher. $\mathrm{O}$ abuso sexual é um crime. Porém, a vida sexual dos adultos é um assunto privado e não deve ser regrada pela religião.

\section{CONCLUSÃO}

Assim, podemos caracterizar o neoateísmo (NAT) com o conjunto NAT (neoateísmo): $<$ I, D, R, M, S, P, E, C, T, G, >. Grosso modo, o NAT sustenta que a crença em Deus e nas doutrinas religiosas não tem fundamento racional. A religião sustenta uma moral primitiva e frequentemente imoral. A religião é um produto natural e ultrapassado, que deve ficar restrito ao uso privado. O Estado, a política e a moral devem ser estabelecidos a partir da razão e da 
ciência, por meios democráticos. Todos os seres humanos são iguais. A vida sexual de adultos deve ser igualmente um assunto privado. Em suma, são enfatizados a razão, o secularismo e a liberdade.

\section{REFERÊNCIAS}

BURLESON, Donald R. Richard Dawkins. In: JOSHI, S. T. Icons of unbelief: atheists, agnostics, and secularists. London: Greenwood Press, 2008.

DAWKINS, Richard. Deus: um delírio. São Paulo: Companhia das Letras, 2013.

DENNETT, Daniel. Quebrando o encanto: a religião como fenômeno natural. São Paulo: Globo, 2006.

GILLILAN, Richard. Daniel Dennett. In: JOSHI, S. T. Icons of unbelief: atheists, agnostics, and secularists. London: Greenwood Press, 2008.

GUTTING, A. On Dawkins's atheism: a response. Disponível em: $<$ http://opinionator.blogs.nytimes.com/2010/08/11/on-dawkinss-atheism-a-response/?_r=1>. Acesso em: 25 ago. 2015.

HARRIS, Sam. A morte da fé: religião, terror e o futuro da razão. São Paulo: Companhia das Letras, 2009.

HITCHENS, Christopher. Dios no es bueno: alegato contra la religión. Barcelona: Random House Mondadori, 2008.

LEDREW, Stephen. Scientism, humanism, and religion: the new atheism and the rise of the secular movement. A dissertation submitted to the Faculty of Graduate Studies. Dec., 2013.

RACHELS, James. Elementos de filosofia moral. Lisboa: Gradiva, 2004.

ZENK, Thomas. New Atheism. Handbook Oxford of Atheism. New York: Oxford University Press, 2014. 